\title{
DEFENSE OF BRACKEN FERN BY ARTHROPODS ATTRACTED TO AXILLARY NECTARIES
}

\author{
By Matthew M. Douglas \\ Adjunct Senior Research Scientist \\ Snow Entomological Museum \\ The University of Kansas*
}

\section{INTRODUCTION:}

The phenotypically variable bracken fern, Pteridium aquilinum (L.) Kuhn, is an economically important plant that establishes dense monocultural stands by spore dispersal and by spreading subterranean rhizomes throughout the world, except for hot and cold desert regions (Page, 1976). Bracken produces a number of so-called "secondary plant compounds" that have been shown to protect it from some nonadapted insects (Cooper-Driver et. al., 1977). These compounds include the cyanogenic glucoside, prunasin (CooperDriver and Swain, 1976; Cooper-Driver et. al., 1977), lignins and silica (Lawton, 1976), sesquiterpene pterosins (Jones and Firn, 1979a), phytoecdysteroids (Jones and Firn, 1978), and the protein thiaminase (Evans, 1976). Tannins, flavonoids, and phenolics have also been implicated as possible defensive compounds in bracken fern (Cooper-Driver et. al., 1977; Jones and Firn, 1979b).

Despite bracken's well-developed biochemical arsenal, adapted and nonadapted herbivorous insects in experimental plots located in Michigan and Massachusetts often destroy up to 30 percent of a frond's biomass after the pinnae are completely expanded. In addition to these herbivores, stands of Michigan bracken also support a diverse community of ectoparasites, parasitoids, and predators of bracken herbivores, including nearly 20 species of ants and spiders that form temporary symbiotic relationships with the bracken croziers.

*Research Address: 1503 Woodland St., Jenison, Michigan, 49428

Manuscript received by the editor May' 2, 1983 


\section{Methods and Study Sites}

During 1980-1982, Gordon VanWoerkom (Hope College) and I observed the relationships between bracken fern and its associated arthropod community in Michigan. Our original intent was to determine to what extent seasonal patterns of insect species diversity are a reflection of quantitative or qualitative changes in the chemical composition of their host plant. We uncovered an arthropod community associated with bracken that is much more complex than expected. These arthropods were identified to species whenever possible, and their behavior was recorded by $16 \mathrm{~mm}$ and $35 \mathrm{~mm}$ cameras.

The bracken-arthropod study was conducted on four $100-\mathrm{m}^{2}$ plots of bracken occupying different environments within the confines of the Hope College Field Station. This 80 acre field station is located in Allegan County, 2 miles south of Holland, Michigan. The mild climate of the preserve is due to the thermal moderating effect of Lake Michigan. Primary vegetation consists of virgin forest, mature (second generation) deciduous forest, as well as open fields punctuated with sand "blow-outs" in various stages of ecological succession.

In upland areas, where the bracken plots are located, the soil consists of a relatively thin layer of sandy-loam topsoil overlying what was formerly extensive sand dunes from Lake Nipissing. Bracken fern has established extensive stands in discrete patches throughout the preserve, some under forest canopy and others under open field conditions.

\section{RESULTS}

Although predaceous ants and spiders are abundant during the spring, the diversity of herbivorous species is low, supporting Lawton's (1976) observation that, "The evidence strongly suggests that bracken in May and June may not be an easy resource for herbivores to exploit." However, protein levels are highest in the spring (about 25 percent of the dry weight) and 40 percent lower by August-September (about 10 percent of the dry weight). Furthermore, concentrations of lignins, tannins, and silicate are lowest in the early spring and tend to increase throughout most of the season, all of which might be expected to make the plants tougher and therefore less palatable. As Lawton (1976) further points out, 
"...bracken-feeding herbivores face progressive deterioration in "food quality" as the growing season progresses." Yet, we have found that herbivorous species diversity and abundance, particularly of adapted herbivores, increase dramatically after the second week of June, and peak during late July and August.

Bracken's palatability early in the spring may also be affected by the production of thiaminase and the cyanogenic glucoside, prunasin (Jones and Firn, 1978). But bracken in England is polymorphic for the production of HCN: some bracken clones contain the B-glucosidase enzyme and not prunasin, while others contain neither enzyme nor the glucoside (Cooper-Driver and Swain, 1976; Cooper-Driver et al., 1977). Likewise, Zavitkovsky (1979) found uniformly negative results for cyanogenesis in Massachusetts bracken fern.

Thiaminase may be the only known chemical deterrent in bracken with any potential for disrupting normal insect development, since thiamine is essential to insect development (Dadd, 1973). However, bracken does contain thiamine (Berti and Bottari, 1968), and thiaminase activity in English bracken drops from a high of nearly $30 \mathrm{ug}$ to $7 \mathrm{ug}$ thiamine destroyed per $\mathrm{min} / \mathrm{g}$ dry weight between the last week of April and the second week of May (Evans, 1976). Even so, populations of adapted bracken herbivores increase only after the second week of June in Michigan, perhaps weeks after cyanogenic glucosides (if functional) and thiaminase activity have fallen to low levels. By contrast, most other diapausing and temperature sensitive insects such as butterflies have eclosed from the pupae by early May in Michigan, and their larvae can be found by the second and third weeks of May.

Our study in Michigan suggests that bracken has evolved another line of defense that complements its biochemical defense system, and protects it from serious herbivorous damage during the rapidlydeveloping crozier stage. This second line of defense consists of predaceous arthropods, particularly ants and spiders attracted to a sweet, viscous fluid secreted by a number of axillary nectaries. The nectaries are dark oval enlargements that appear in the axils where the pinnae and major pinnules branch off from the rachis. Large numbers of "nonassociated" arthropods which utilize bracken for purposes other than food are also attracted to the developing bracken canopy and their oozing nectaries early in the spring. In 
turn, these nonassociated arthropods are preyed upon by the predaceous ants and spiders. Biochemical analyses of nectary secretions in California bracken indicate the presence of relatively large concentrations of glucose and fructose, minute concentrations of sucrose and maltose (Irene Baker and Peter Atsatt, pers. comm.), and an undetermined number of free amino acids.

By mid-May, when the primary nectaries at the axils of the pinnae are secreting microliters of "nectar" daily, the thiaminase activity is declining rapidly and the cyanogenic glucoside may or may not be offering protection. In addition, the levels of tannins and silicate are still at low levels, while proteins are at optimal level (Lawton, 1976). Thus, the crozier stage of bracken may at once present a nutritious stage to attack as well as a "loophole" in the biochemical arsenal. The potential for attack at this time by nonadapted polyphagous herbivores is great, and we have established that several nonadapted herbivores will feed readily on bracken croziers without ill effect. These include the gypsy moth, Porthetria dispar (L.) (Lepidoptera: Liparidae), the large milkweed bug, Oncopeltus fasciatus (Dallas) (Hemiptera: Lygaeidae), the common rose chafer, Macrodactylus subspinosus (Fabricius) (Coleoptera: Scarabaeidae), and a large tropical cockroach, Blaberus giganteus (L.) (Orthoptera: Blaberidae).

Many croziers are not attacked because their actively secreting nectaries are quickly located by at least five species of ants in Michigan: Formica subsericea Say, Formica obscuriventris Mayr, Formica pallidefulva nitidiventris Emery, Camponotus pennsylvanicus (De Geer), and Camponotus nearcticus Emery. Camponotus pennsylvanicus, Formica obscuriventris, and Formica subsericea in particular defend the nectaries and the developing crozier by patrolling the plant in a very systematic manner. An ant patrol typically begins after both primary nectaries at the base of the pinnae are antennated and sampled with the mouthparts for 1-3 minutes. The ant then proceeds up and down each pinna, investigating the pinnules and attenating the smaller nectaries even though these rarely secrete visible quantities of nectar. A single patrol, covering the entire frond, may last from 2 to 15 minutes, depending upon the size of the crozier and the length of the time spent at each nectary.

One ant, or several ants from the same colony may patrol a given crozier, but all other "intruding" arthropods are bitten and stung 
until they are driven off or killed by the patrolling ant(s). Corpses are removed and taken down to the nest. Patrolling predaceous ants thus obtain both a nutrient-rich secretion in addition to arthropod prey attracted directly to the plant tissues or to the nectaries. The result is that the croziers are protected (to an unknown extent) from adapted and nonadapted herbivores during this most susceptible stage of growth).

Species of smaller ants such as Tapinoma sessile (Say), Leptothorax curvispinosus Mayr, Leptothorax muscorum (Nylander) and Lasius alienus (Foerster) engorge at the nectaries as well, but often in non-aggressive interspecific groups. However, none of these species appears to defend the bracken croziers from other arthropods, and thus they may be "parasitic" in the broad sense of the concept since the ants obviously benefit by gathering nectar, but the bracken potentially suffers because it loses its attraction to more aggressively-defensive ants. Although we have not documented any defensive role by these small ants in Michigan, it is possible that they remove the eggs of herbivores (Susan Koptur, pers. comm.).

The immatures of at least 10 species of spiders also imbibe at or are attracted to the axillary nectaries, while several others are intimately associated with the unfurling pinnae. For example, when the immatures of Enoplognatha ovata (Clerck) bind the 3 pinnae together, the nectaries become effective "baits" within the pyramidal web, ensnaring many smaller nonassociated dipterans and parasitic ants. Other spiders such as the thomisid Tibellus sp. extend their body against the rachis, cepthalothorax pointing towards the nectary, and ambush other arthropods as they arrive to extract nectar. Finally, several species of salticid spiders (e.g. Metaphiddipus protervus Walckenaer), prowl the developing bracken canopy, leaping from pinna to pinna in search of prey. Encounters between spiders and patrolling ants are not uncommon, but it is not certain which factors predispose one or the other to dominate a given frond. However, the small parasitic ants are common prey items of the patrolling spiders in Michigan.

By the second week of June, the pinnae have completely opened, and the nectaries darken and desiccate. Even so, patrolling ants continue to defend the mature plants for a few more days, perhaps attracted to the lingering odor of the nectaries. But the ant patrols are erratic and the ants stay on the plants for far shorter periods, 
usually less than 30 seconds. At the end of June, defending ants and spiders cease patrolling the fronds entirely, although mature Metaphiddipus protervus spiders and Formica subsericea ants can occasionally be found on new croziers which emerge periodically throughout the growing season. As with spring croziers, these summer fiddleheads are also patrolled systematically by ants, even though their nectaries appear to dry quickly under the hot sun.

Concurrently with the declines in the ant patrols and the spider populations associated with bracken, there is a significant increase in herbivore damage, largely from adapted insects. Damage increases as adapted insect populations peak in mid to late summer, despite the "toughening" of the bracken with increasing concentrations of tannins and silicate, and despite the fact that available protein has declined by over 40 percent (Lawton, 1976). Any herbivore damage done at maturity, however, will affect proportionately less of the plant biomass than if the plant had incurred the damage during the crozier stage. Even minor chewing or sucking damage on the newly-emergent croziers can destroy part or all of the apical bud, or cause lodging of the plant at maturity if the rachis is weakened. Lodging or individual pinna or the entire frond is especially common in bracken plants attacked by minute gall-forming/mining microlepidopterans, as yet unidentified. These mining insects can stunt 50 to 90 percent of the potential growth of a given pinna, possibly because they feed on internal vascular tissues and cannot be reached by patrolling ants or predaceous spiders.

\section{SUMMARY}

Darwin (1877) was among the first to point out that the secretion of the bracken nectaries is very attractive to ants and that the ants may thus serve in some capacity to defend the ferns (Lawton, 1976). The arthropod defense system found in Michigan may help to explain why herbivorous damage from both adapted and nonadapted insects is minimal in the crozier stage. Bracken fern has a well-developed "arsenal" of potentially toxic secondary plant compounds that may also serve to deter or inhibit insects from attack. Yet, despite a relatively herbivorous-free period during its early growth stage, a diverse community of adapted herbivorous insects inflicts moderate to heavy damage later in the summer months. 
Bracken may (in part) be protected by compounds such as thiaminase and cyanogenic glucosides, but our research of the past three years shows that bracken at the very least supplements its passive chemical defenses with a mobile, predaceous arthropod defense community. This community includes at least 5 species of ants and 10 species of spiders that are initially attracted to "axillary nectaries" (AN) secreting a nutrient-rich sap of sugars and amino acids. Our research shows that bracken "turns on" these nectaries during the rapidly-growing crozier stage, and turns them "off" after the pinnae are fully expanded. During the secretory stage, ants patrol and defend the pinnae from all intruders, including potential herbivores, other species of ants, and other predaceous arthropods such as spiders. However, the immature spiders also utilize the AN secretions, stalk arthropods within the developing canopy, or construct webs over the opening pinnae, turning them into effective traps with the AN enclosed as "baits."

Bracken's apparent immunity to insect attack during the crozier stage may be due not so much to the toxicity of its secondary compounds, but to the continuing coevolution of the AN and their attendant, predaceous arthropods that patrol the pinnae or otherwise rid them of herbivores during bracken's crozier stage. The bracken-arthropod system may be one of the most unique and complex hierarchies of symbiotic relationships to be found in a primitive plant-arthropod system.

\section{ACKNOWLEDGMENTS}

This study was supported in part by NSF grant DEB-8005581 (Gillian Cooper-Driver, Principle Investigator), and conducted at the Hope College Research Station, Holland, Michigan. I thank Gordon VanWoerkom and Annmarie Baldiga for their invaluable assistance in the field and laboratory. I also thank Drs. Irene Baker, Susan Koptur, and Peter Atsatt for use of unpublished information. Drs. O. Taboada, H. D. Blocker, R. E. Beer, M. DuBois, C. D. Michener, A. Brady, G. Byers, O. R. Taylor, W. H. Wagner and especially G. Cooper-Driver assisted me in various stages of this project and the preparation of the manuscript. 


\section{Literature Cited}

Berti, G. ANd F. Bottari

1968. Constituents of ferns. In L. Reinhold and Y. Liwschitz (Eds.), Progress in Phytochemistry. 1: 589-685, London: Interscience.

Cooper-Driver, G., Finch, S., Swain, T. and E. Bernays.

1977. Seasonal variation in secondary plant compounds in relation to the palatability of Pteridium aquilinum. Biochem. Syst. Ecol., 5: 211-218.

CoOper-Driver, G. AND T. Swain

1976. Cyanogenic polymorphism in bracken in relation to herbivore predation. Nature (London), 260: 604.

DADD, R. H.

1973. Insect nutrition: current developments and metabolic implications. Ann. Rev. Ent., 18: 382-419.

DARWIN, F.

1877. On the glandular bodies of Acacia sphaerocephala and Cecropia peltata serving as food for ants, with an appendix on nectar-glands of the common braken fern, Pteris aquilina. J. Linn. Soc. (Bot.), 15: 398-409.

Evans, W. C.

1976. Bracken thiaminase-mediated neurotoxic syndromes. J. Linn. Soc. (Bot.), 73: 113-132.

Jones, C. G. AND R. D. FiRN

1978. The role of phytoecdysteroids in bracken fern Pteridium aquilinum (L.) Kuhn as defense against phytophagous insect attack. J. Chem. Ecol., 4: 117-138.

1979a. Resistance of Pteridium aquilinum to attack by non-adapted phytophagous insects. Biochem. Syst. Ecol., 7: 95-101.

1979b. Some allelochemicals of Pteridium aquilinum and their involvement in resistance to Pieris brassicae. Biochem. Syst. Ecol., 7: 187-192.

LAWTON, J.

1976. The structure of the arthropod community of bracken Pteridium aquilinum (L.) Kuhn. J. Linn. Soc. (Bot.), 73: 187-216.

PAGE, C. N.

1976. The taxonomy and phytogeography of bracken-a review. J. Linn. Soc. (Bot.), 73: 1-34. 

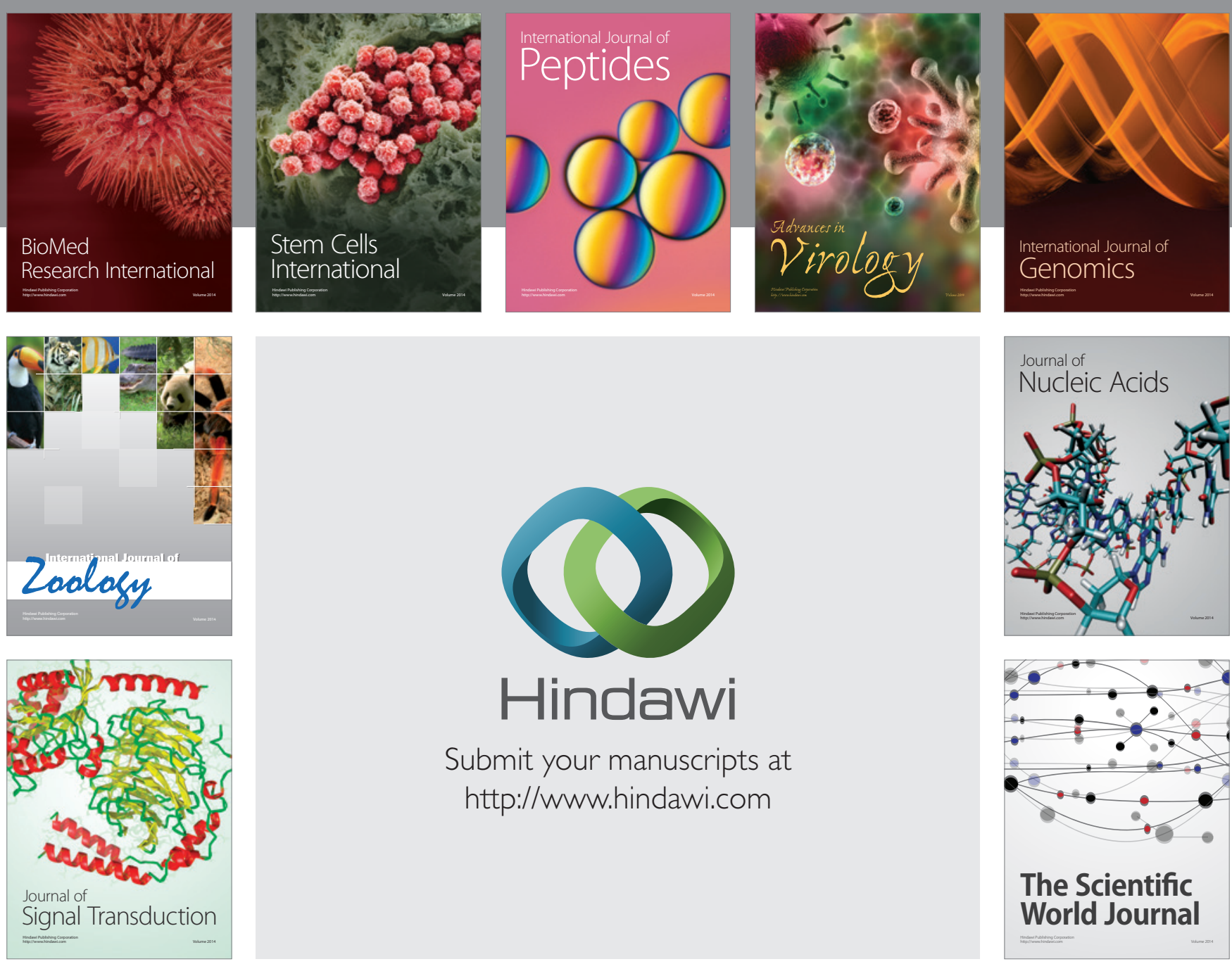

Submit your manuscripts at

http://www.hindawi.com
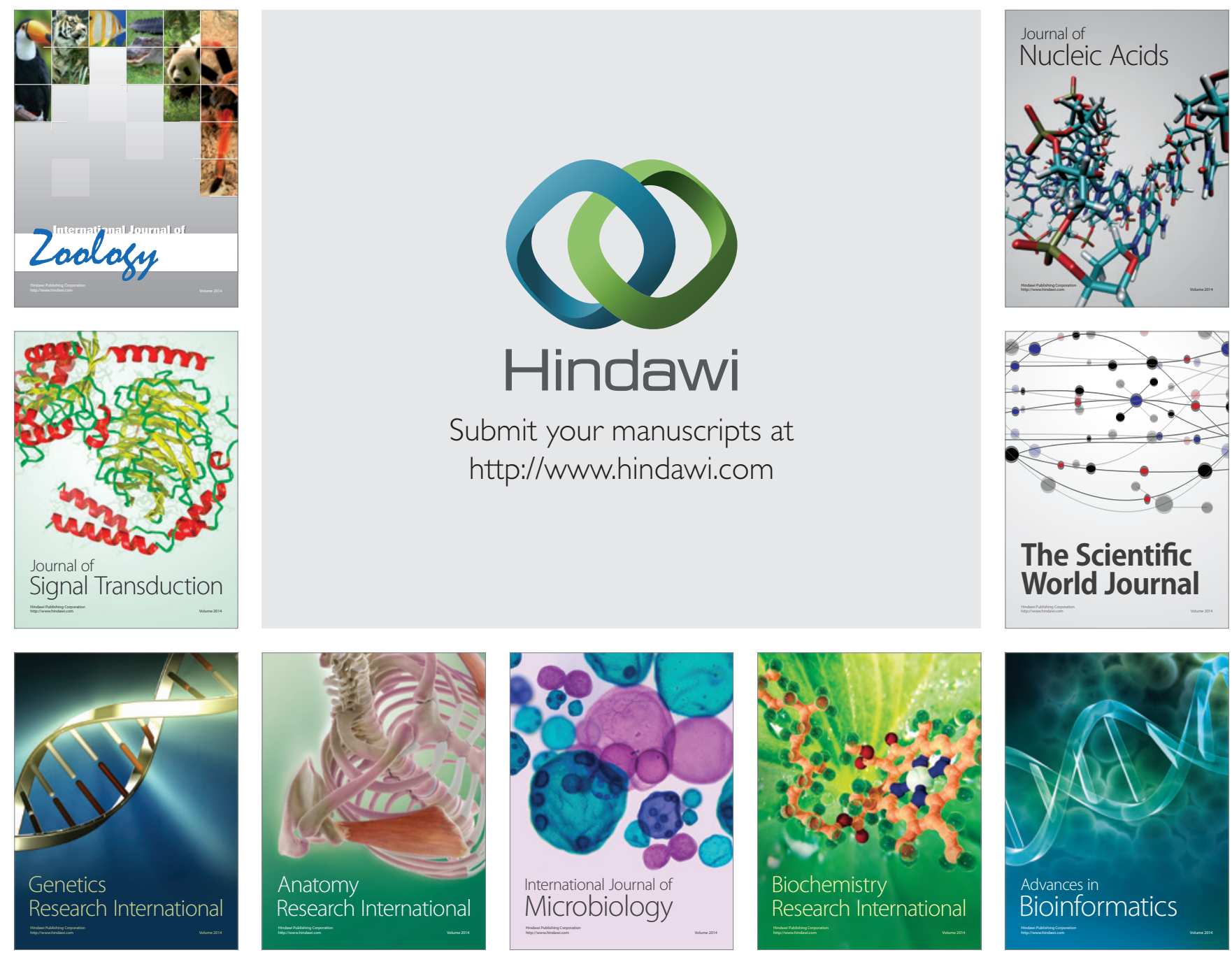

The Scientific World Journal
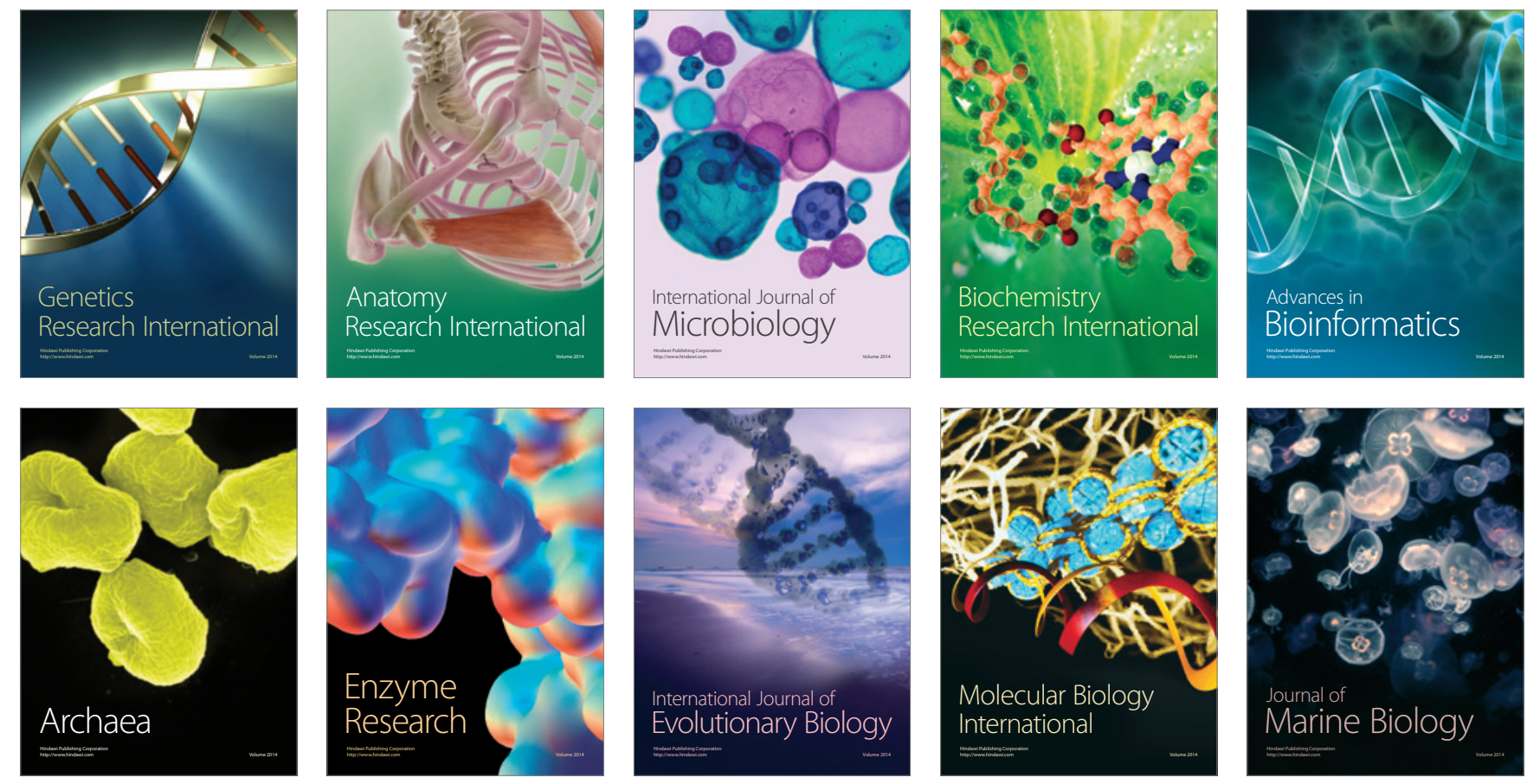